Jurnal Tanah dan Sumberdaya Lahan Vol 8 No 1: 27-34, 2021

e-ISSN:2549-9793, doi: 10.21776/ub.jts1.2021.008.1.4

\title{
PENGARUH PEMBERIAN BIOCHAR TERHADAP BEBERAPA SIFAT BIOKIMIA TANAH DAN PERTUMBUHAN TANAMAN BAWANG MERAH PADA LAHAN TERCEMAR RESIDU PESTISIDA
}

\section{Effect of Biochar Application on Some Biochemical Properties and Growth of Onion on Land Contaminated with Pesticide Resides}

\author{
Sonni Senna Dimas Airlangga ${ }^{1 *}$, Mochammad Munir ${ }^{1}$, Poniman $^{2}$ \\ ${ }^{1}$ Jurusan Tanah, Fakultas Pertanian, Universitas Brawijaya, Jl. Veteran 1, Malang 65145 \\ ${ }^{2}$ Balai Penelitian Lingkungan Pertanian, Pati, Jawa Tengah \\ *Penulis korespondensi: sonnisenna1996@gmail.com
}

\begin{abstract}
The production of shallots in Brebes has not been significantly free from the use of chemical pesticides. Preventive land contaminated with pesticides needs to be done, one of which is through the improvement of polluted land using biochar. The study was aimed to determine the effectiveness of the effect of urea plus nano biochar and urea plus biochar enriched by microbial consortia on the status of $\mathrm{C}$-organic, $\mathrm{pH}$, and soil microbial populations and their effects on profenofos residues. The experiment was designed with a Randomized Block Design with 5 treatments including: $\mathrm{P}$ (without biochar and microbes), B (Urea plus biochar), BM (Urea plus biochar and microbial), NB (Urea plus nano biochar), NBM (Non-biochar and microbial) Urea added with nano biochar and microbes), and repeated 4 times, so that the number of research units was 20 units. The microbes used in enriching urea plus biochar are microbial consortia, Stenotrophomonas maltophilla, Acbromobacter denitrificans, Bacillus cereus, Bacillus subtilis, Bacillus thuringiengsis and Bacillus aryabathai. The results of the study include, the administration of urea plus biochar and nano biochar with microbial consortia did not have a significant effect on $\mathrm{pH}$, C-organics, soil microbial populations and profenofos residues. At 35 and 63 DAP the highest $\mathrm{pH}$ of treatment $\mathrm{B}$ was 5.84 , and 6.53. Organic C-35 and $63 \mathrm{DAP}$ at low criteria are $1.12-1.30 \%$. The highest microbial population of 35 and $63 \mathrm{DAP}$ in treatment $\mathrm{B}$ was $485 \times 10^{6}$. The highest growth rate of plant length in the BM treatment with a value of $6.06 \mathrm{~cm}^{\text {week }}{ }^{-1}$, while the growth rate of the number of leaves in the BM treatment had a higher yield compared to other treatments, with a value of 2.88 strands week ${ }^{-1}$.
\end{abstract}

Keywords : biochar, mikroba consorsia, nano biochar, propenophos, shallots

\section{Pendahuluan}

Produksi bawang merah di Brebes belum nyata terbebas dari penggunaan pestisida kimia. Penggunaannya dianggap masih cukup efektif untuk memberantas hama dan penyakit tanaman. Dalam penggunaan pestisida, yang harus diperhatikan adalah akibat residu yang ditinggalkannya, sedangkan efek toksik residu yang terbawa pada produk yang dikonsumsi dapat merugikan kesehatan. Faktor peningkatan cemaran muncul karena pemakaian pestisida secara menerus, mengabaikan kepatuhan dalam penggunaan dosis, serta pemakaian pestisida yang pengunaannya di luar pengawasan resmi. Lahan tercemar pestisida juga sangat berkontribusi terhadap kandungan residu pestisida dalam produk pertanian, untuk itu perlu dilakukan tindakan pencegahaan, salah satunya melalui perbaikan lahan tercemar.

Di Indonesia, laju dekomposisi (pelapukan) bahan organik tergolong tinggi sehingga bahan pembenah tanah organik alami 


\section{Jurnal Tanah dan Sumberdaya Lahan Vol 8 No 1: 27-34, 2021 e-ISSN:2549-9793, doi: 10.21776/ub.jts1.2021.008.1.4}

yang digunakan lebih bersifat sementara (temporary). Saat ini mulai berkembang penggunaan biochar sebagai bahan pembenah tanah alternatif. Biochar mampu bertahan lama di dalam tanah dan relatif resisten terhadap serangan mikroorganisme, sehingga proses dekomposisi berjalan lambat (Tang et al., 2013). Penggunaan biochar bertujuan untuk immobile pestisida dalam tanah, sehingga tidak mencemari lingkungan di sekitarnya. Biochar adalah teknologi baru untuk mengurangi pencemaran lingkungan pertanian dari residu pestisida. Untuk itu teknologi ini perlu dilakukan pengkajian supaya diperoleh hasil yang bermanfaat untuk menanggulangi pencemaran.

Urea yang ditambahkan biochar, dapat meningkatkan efektivitas penyerapan oleh tanaman dan biochar dapat berperan dalam menurunkan konsentrasi pestisida di dalam tanah maupun air karena adanya mikroba tanah yang berperan aktif dalam memanfaatkan sumber karbon dari pestisida. Inovasi nano biochar merupakan inovasi yang relatif baru, berasal dari biochar yang dibuat dengan ukuran nano dengan ukuran $1-100 \mathrm{~nm}$. Nano biochar diharapkan dapat memperbaiki inovasi teknologi yang telah ada. Perlakuan biochar dan nono biochar dibuat dengan cara mencampurkannya dengan pupuk urea. Dengan prinsip pupuk urea mudah menguap, penambahan biochar dan nano biochar dengan merekatkan pada dinding urea dapat mengurangi hilangnya pupuk urea saat diaplikasikan pada tanaman budidaya.

Tujuan dalam penelitian ini adalah untuk mengetahui pengaruh pemberian kombinasi urea ditambah biochar, nano biochar dan mikroba konsorsia terhadap ketersediaan C-organik, pH, populasi mikroba tanah dan laju pertumbuhan bawang merah pada tanah tercemar residu pestisida profenofos.

\section{Bahan dan Metode}

\section{Waktu dan tempat penelitian}

Penelitian ini dilaksanakan dari bulan Maret 2018 sampai dengan Agustus 2018. Budidaya bawang merah dilakukan di Rumah Kasa Balai Penelitian Lingkungan Pertanian, Pati, Jawa Tengah. Analisis kimia dan biologi tanah dilaksanakan di Laboratorium Terpadu Balai
Penelitian Lingkungan Pertanian, Pati, Jawa Tengah.

\section{Alat dan bahan}

Alat yang digunakan pada penelitian ini antara lain Spectrophotometer, Gas Chromatography (GC), $\mathrm{pH}$ meter, destruktor, destilator, laminary air flow, autoclaf, vortex, ependorf, labu ukur $100 \mathrm{ml}$, pipet 5 $\mathrm{ml}$, oven, tabung erlemenyer, timbangan analitik, saringan tanah ukuran $2 \mathrm{~mm}$ dan $0,5 \mathrm{~mm}$, shaker, alat pelapisan urea dan biochar (penggiling), HEM-E3D (alat pembuatan anno biochar) dan alat-alat penelitian lainnya. Bahan yang digunakan antara lain bibit bawang merah varietas Bima Curut (seleksi lokal Brebes), tanah, pupuk (urea, NPK, KCl dan SP-36), biochar, mikroba konsorsia (Stenotrophomonas maltophilla, Achromobacter denitrificans, Bacillus cereus, Bacillus subtilis, Bacillus thuringiengsis dan Bacillus aryabathai) dan bahan-bahan kimia lainnya.

\section{Pelaksanaan Penelitian}

Penelitian ini berupa penelitian lapang yang dilakukan di Rumah Kasa Balai Penelitian Lingkungan Pertanian, menggunakan Rancangan Acak Kelompok dengan 5 perlakuan diulang 4 kali.

\section{Pembuatan Biochar}

Pada tahap ini kegiatan yang dilakukan meliputi persiapan bahan tongkol jagung kering $\pm 300 \mathrm{~kg}$ dalam sekali pembakaran dan kemudian ditata rapi dalam tungku pembakaran. Selanjutnya, menutup tungku pembakaran dan memastikan semua lubang tertutup rapat, lalu nyalakan api sampai suhu dalam tungku mencapai $300-400^{\circ} \mathrm{C}$ selama 1 x 24 jam. Kamudian mematikan api dan buka penutup tungku untuk mempercepat pendinginan. Setelah dingin \pm 1 hari, penutup tungku dibuka dari samping untuk mengeluarkan biochar tongkol jagung dari dalam tungku pembakaran. Biochar kemudian dihaluskan dengan ukuran $\pm 2 \mathrm{~mm}$.

Penambahan urea pada biochar

Pada kegiatan ini yang dilakukan adalah menyiapkan biochar dan urea yang akan digunakan, kemudian masukkan urea $80 \%$ (40 $\mathrm{kg}$ ) ke dalam pan granulator. Tambahkan biochar secara sedikit demi sedikit sebanyak $0,25 \mathrm{~kg}$, lalu tambahkan molase $2 \%(12,5 \mathrm{ml})$. 


\section{Jurnal Tanah dan Sumberdaya Lahan Vol 8 No 1: 27-34, 2021 \\ e-ISSN:2549-9793, doi: 10.21776/ub.jts1.2021.008.1.4}

Penambahan dilakukan sebanyak 4 kali hingga tercampur rata, kemudian dikeringanginkan.

\section{Pembuatan nano biochar}

Pembuatan nano biochar dilakukan dengan metode top down menggunakan high energy milling (HEM-E3D) yaitu menggiling bahan awal (biochar tongkol jagung) dengan alat milling. Rasio yang digunakan yaitu 1:8. Diawali dengan menyiapkan biochar yang akan dinanokan. Setiap proses milling, dimasukkan biochar sebanyak 4,84 g dengan 11 buah bola penggiling yang memiliki berat masing-masing 3,52 $\mathrm{g}$ dimasukkan dalam tabung (jar) HEM-E3D selama 30 detik dengan kecepatan $800 \mathrm{rpm}$.

\section{Penambahan mikroba}

Mikroba tanah yang digunakan adalah mikroba konsorsia, yang terdiri atas Stenotrophomonas maltophilla, Achromobacter denitrificans, Bacillus cereus, Bacillus subtilis, Bacillus thuringiengsis dan Bacillus aryabathai. Pada tahap ini kegiatan yang dilakukan adalah menyiapkan larutan mikroba dan urea ditambah biochar yang akan digunakan. Kegiatan ini dilakukan dengan teknik penyemprotan, dengan komposisi larutan mikroba $40 \mathrm{ml}$ dalam $1000 \mathrm{~g}$ urea ditambah biochar. Penyemprotan dilakukan pada permukaan biochar menggunakan sprayer dan dilakukan dalam granulator sambil berputar. Penyemprotan dilakukan secara bertahap agar urea tidak ikut terlarut oleh larutan mikroba, selanjutnya urea biochar dikeringanginkan dan diwadahi serta dihindarkan dari sinar matahari langsung karena dapat mematikan mikroorganisme yang telah ditambahkan ke dalam urea ditambah biochar.

\section{Pelaksanaan di lapangan}

Kegiatan yang dilakukan selama penelitian di lapangan meliputi persiapan media tanam, penanaman bawang merah pada pot yang sudah disediakan, pemupukan dilakukan 3 kali selama penelitian, pemeliharaan yang meliputi penyiraman dan perawatan dari gulma, dan diakhiri dengan kegiatan panen.

\section{Pengamatan penelitian}

Parameter pengamatan meliputi:

(1) Tanah rutin; C-organik, Mikroba total, dan $\mathrm{pH} \quad\left(\mathrm{H}_{2} \mathrm{O}\right)$ dan analisa residu profenofos. Pengambilan sampel sebanyak 3 kali (sebelum perlakuan 0 HST, setelah perlakuan 35 HST dan panen 63 HST), (2) Parameter tanaman yaitu pertumbuhan tanaman bawang merah (panjang tanaman dan jumlah daun) diamati pada tanaman umur 14, 21, 28, 35, 42, 49, dan 56 HST, dan (3) Perhitungan laju pertumbuhan bawang merah dengan menggunakan rumus:

$$
\mathrm{W}=\frac{\operatorname{Ln} \mathrm{Nt}-\mathrm{Ln} \mathrm{No}}{\mathrm{t}}
$$

Dimana: $\mathrm{W}=$ laju pertumbuhan, $\mathrm{Nt}=$ pertumbuhan bawang merah waktu ke $\mathrm{t}$ (minggu $1 \mathrm{~s} / \mathrm{d}$ minggu ke 8 ), No = pertumbuhan bawang merah awal, dan $\mathrm{t}=$ waktu pengamatan (per minggu)

Pengumpulan data

Sampel tanah selanjutnya dilakukan analisis kimia tanah di laboratorium Terpadu BALINGTAN. Parameter yang di analisis adalah C-organik (metode Walkley dan Black), residu profenofos (metode QuEChERS), mikroba total (metode PCAS), dan $\mathrm{pH}$ (metode ekstrak $\mathrm{H}_{2} \mathrm{O}$ ). Hasil dari kegiatan analisis sampel tanah akan dilakukan klasifikasi berdasarkan status dari parameter yang diamati berdasarkan ketetapan yang berlaku.

\section{Analisa data}

Jumlah perlakuan yang digunakan dalam penelitian ini sebanyak lima buah dengan empat kali ulangan sehingga rancangan penelitiaan berjumlah 20 unit. Rancangan penelitian yang digunakan adalah Rancangan Acak Kelompok (RAK). Data hasil analisis tanah, tanaman dan pupuk dianalisis Ragam menggunakan aplikasi Genstat 12th Edition. Jika hasil analisis ragam berbeda nyata maka dilanjutkan dengan uji Duncan's Multiple Range Test (DMRT).

\section{Hasil dan Pembahasan}

\section{Karakteristik tanah sebelum perlakuan}

Berikut hasil analisis karakteristik tanah tercemar residu pestisida sebelum perlakuan. Hasil analisis tanah awal sebelum perlakuan sebagaimana disajikan pada Tabel 1. Hasil analisis dasar tanah menunjukkan bahwa kandungan residu profenofos 0,160 ppm kriteria tinggi dengan nilai diatas Batas Maksimum Residu (BMR) residu profenofos 


\section{Jurnal Tanah dan Sumberdaya Lahan Vol 8 No 1: 27-34, 2021 e-ISSN:2549-9793, doi: 10.21776/ub.jts1.2021.008.1.4}

pada pertanaman bawang merah 0,1 $\mathrm{ppm}$ (Afriyanto, 2008). Pada hasil analisa sifat kimia tanah menunjukkan bahwa nilai $\mathrm{pH}$ bersifat netral dengan nilai 6,89 .

Tabel 1. Hasil analisis tanah awal sebelum perlakuan.

\begin{tabular}{lcc}
\hline Parameter & Nilai & Kriteria \\
\hline C-organik (\%) & 1,95 & $\mathrm{r}$ \\
$\mathrm{pH}$ & 6,89 & $\mathrm{n}$ \\
$\begin{array}{l}\text { Mikroba total } \\
\left(\mathrm{cfu} \mathrm{ml}^{-1}\right)\end{array}$ & $604 \times 10^{6}$ & - \\
$\begin{array}{l}\text { Residu profenofos } \\
(\mathrm{ppm})\end{array}$ & 0,160 & - \\
\hline
\end{tabular}

Kriteria penilaian hasil analisis tanah berdasarkan Balai Penelitian Tanah (2009). sr = sangat rendah; $r$ $=$ rendah; $\mathrm{t}=$ tinggi; $\mathrm{am}=$ agak masam; $\mathrm{st}=$ sangat tinggi; $\mathrm{n}=$ netral; $\mathrm{aa}=$ agak alkali.

Menurut Wibowo (2007) tanah yang baik untuk pertanaman bawang merah adalah tanah yang memiliki pH 6,0-6,8. Hal lain juga didukung dengan tingginya nilai $\mathrm{N}$-total pada tanah dengan nilai $0,67 \%$ kriteria tinggi. Nilai Corganik 1,95\% dengan kriteria rendah dan memiliki jumlah total mikroba sebesar $604 \times 10^{6}$ cfu $\mathrm{ml}^{-1}$. Ketersediaan C-organik sebagai sumber energi, apabila ketersediaan C-organik berlebihan akan menghambat perkembangan mikroorganisme karena C-organik yang berlebihan dibandingkan N-total. Hal tersebut akan menghambat pembentukan protein yang dibutuhkan oleh mikroorganisme dalam tanah. C-organik dan $\mathrm{N}$-total dapat digunakan untuk mengetahui nilai $\mathrm{C} / \mathrm{N}$ ratio atau tingkat pelapukan dan kecepatan penguraian bahan organik serta ketersedian nutrisi dalam tanah (Bachtiar, 2006). Apabilai nilai $\mathrm{C} / \mathrm{N}$ rasio tinggi $>25$, maka proses dekomposisi bahan organik dapat terjadi immobilisasi, akumulasi bahan organik dan peningkatan kadar sulfur yang menyebabkan proses berjalan lambat. Nilai $\mathrm{C} / \mathrm{N}$ rasio rendah $<25$ akan menyebabkan proses dekomposisi berjalan dengan cepat.

\section{Pengaruh perlakuan terhadap beberapa sifat tanah}

Pengujian beberapa sifat kimia tanah berupa residu profenofos, populasi mikroba, $\mathrm{pH}$ dan $\mathrm{C}-$ organik tanah dilakukan dua kali setelah perlakuan, yaitu pada 35 HST dan 63 HST. Berikut adalah hasil analisis karakteristik tanah tercemar residu pestisida setelah perlakuan.

\section{pH tanah}

Hasil sidik ragam menunjukkan bahwa pemberian perlakuan urea ditambah biochar, urea ditambah biochar dengan mikroba, urea ditambah nano biochar, urea ditambah nano biochar dengan mikroba dan pupuk NPK tidak memberikan pengaruh yang nyata terhadap $\mathrm{pH}$ tanah 35 HST dan 63 HST. Hasil analisis pH tanah sebagaimana disajikan dalam Tabel 2 .

Tabel 2. Hasil analisis pH tanah.

\begin{tabular}{lcccc}
\hline Perlakuan & \multicolumn{4}{c}{$\mathrm{pH}$} \\
\cline { 2 - 5 } & $\mathbf{3 5}$ & Kriteria & $\mathbf{6 3}$ & Kriteria \\
& HST & & HST & \\
\hline P & 5,64 & Am & 6,46 & Am \\
BM & 5,83 & Am & 6,52 & Am \\
NBM & 5,83 & Am & 6,51 & Am \\
NB & 5,75 & Am & 6,04 & Am \\
B & 5,84 & Am & 6,53 & am \\
\hline
\end{tabular}

Keterangan : Kriteria penilaian $\mathrm{pH}$ tanah berdasarkan Balai Penelitian Tanah (2009). sm = sangat masam; $\mathrm{m}=$ masam; $\mathrm{am}=$ agak masam $; \mathrm{n}=$ netral; aa $=$ agak alkalis; $\mathrm{a}=$ alkalis. $\mathrm{P}=$ Perlakuan Petani (tanpa biochar + Urea, SP-36 dan $\mathrm{KCl}$ ), BM = Urea ditambah biochar dengan mikroba + SP-36 dan $\mathrm{KCl} . \mathrm{NB}=$ Urea ditambah nano biochar dengan mikroba + SP-36 dan KCl. NB = Urea ditambah nano biochar $+\mathrm{SP}-36$ dan $\mathrm{KCl} . \mathrm{B}=$ Urea ditambah biochar + SP-36 dan $\mathrm{KCl}$.

Pada pengamatan 35 HST, nilai tertinggi yang mendekati $\mathrm{pH}$ netral pada perlakuan $\mathrm{B}$ dengan nilai $\mathrm{pH} 5,84$. Tingginya nilai $\mathrm{pH}$ pada perlakuan B diduga akibat adanya pemberian bahan pembenah tanah berupa biochar yang berukuran granul. Penambahan biochar ke tanah dapat meningkatkan ketersediaan kation utama, $\mathrm{pH}$ dan KTK. Biochar terhadap $\mathrm{pH}$ dapat meningkat sampai satu unit $\mathrm{pH}$. Tingginya ketersediaan hara bagi tanaman juga merupakan hasil dari bertambahnya nutrisi dari biochar dan meningkatnya retensi hara (Chan et al., 2007). Penurunan $\mathrm{pH}$ disebabkan oleh proses dekomposisi pupuk organik biochar yang dilapiskan ke urea mengakibatkan penambahan asam-asam organik. Berdasarkan Rahayu dan Berlian (2010) menyatakan bahwa asam organik sederhana mampu menyumbangkan ion 


\section{Jurnal Tanah dan Sumberdaya Lahan Vol 8 No 1: 27-34, 2021 \\ e-ISSN:2549-9793, doi: 10.21776/ub.jts1.2021.008.1.4}

hidrogen $(\mathrm{H}+)$ sebagai sumber kemasaman. Selain itu, penurunan nilai $\mathrm{pH}$ tanah ini dapat dipengaruhi oleh bakteri Nitrosomonas dan Nitrobacter pada proses nitrogen pada tahap nitrifikasi. Hal ini sebanding dengan pernyataan Agustin dan Suntari (2018), bahwa kemasaman tanah dapat dipengaruhi oleh mikroorganisme dalam penyerapan unsur sehingga dapat menurunkan nilai $\mathrm{pH}$ tanah. Pada pengamatan 63 HST, nilai $\mathrm{pH}$ tanah yang tertinggi terdapat pada perlakuan $\mathrm{B}$ dengan nilai $\mathrm{pH}$ sebesar 6,53. Berdasarkan penilaian Balai Penelitian Tanah, nilai $\mathrm{pH}$ tersebut tergolong pada kriteria netral. Nilai pH terendah pada perlakuan NB dengan nilai $\mathrm{pH}$ sebesar 6,04 pada kriteria agak masam. Peningkatan nilai $\mathrm{pH}$ pada perlakuan $\mathrm{B}$ diduga akibat adanya penambahan bahan pembenah berupa biochar. Biochar merupakan bahan organik berasal dari limbah pertanian yang dibakar dengan suhu tinggi tetapi tidak sampai menjadi abu. Menurut Lehmann dan Joseph (2009) biochar diproduksi dari bahan-bahan organik yang sulit terdekomposisi, yang dibakar secara tidak sempurna (pyrolisis) atau tanpa oksigen pada suhu yang tinggi. Biochar yang sudah terdekomposisi dapat meningkatkan kapasitas tukar kation. Sebagai dasar untuk meningkatkan kation basa sehingga secara relatif menurunkan kation asam. Ketersediaan biochar/bahan organik dalam tanah dibutuhkan dalam jumlah yang banyak untuk membantu mencukupi hara tanaman. Biochar akan lebih efektif apabila diberikan dalam jumlah yang lebih banyak $>50$ t ha ${ }^{-1}$ (Sohi et al., 2009).

C-organik

Berdasarkan hasil sidik ragam menunjukkan bahwa pemberian perlakuan urea ditambah biochar, urea ditambah biochar dengan mikroba, urea ditambah nano biochar, urea ditambah nano biochar dengan mikroba dan pupuk NPK tidak memberikan pengaruh yang nyata terhadap Corganik tanah 35 HST dan 63 HST. Hasil analisis C-organik tanah sebagaimana disajikan dalam Tabel 3. Hasil analisis C-organik tanah pada 35 HST dan 63 HST, didapatkan nilai Corganik 1,12 - 1,30\% dengan kriteria rendah. Kriteria penetapan C-organik tersebut diambil berdasarkan hasil analisa Balai Penelitian Tanah (2009). Berdasarkan hasil tersebut dapat diketahui bahwa adanya proses dekomposisi yang berjalan, sehingga hasil dari C-organik menurun dibandingkan dengan analisa awal tanah dari semua perlakuan. Proses dekomposisi biochar juga berjalan lambat, hal ini didukung dengan pernyataan Tang et al., (2013) bahwa biochar sebagai bahan pembenah tanah mampu bertahan lama di dalam tanah atau mempunyai efek yang relatif lama, atau relatif resisten terhadap serangan mikroorganisme, sehingga proses dekomposisi berjalan lambat.

Tabel 3. Hasil analisis C-organik tanah (\%).

\begin{tabular}{lcccc}
\hline Perlakuan & \multicolumn{4}{c}{ C-organik (\%) } \\
\cline { 2 - 5 } & $\mathbf{3 5}$ & Kriteria & $\mathbf{6 3}$ & Kriteria \\
& HST & & HST & \\
\hline P & 1,28 & $\mathrm{R}$ & 1,24 & $\mathrm{r}$ \\
$\mathrm{BM}$ & 1,23 & $\mathrm{R}$ & 1,12 & $\mathrm{r}$ \\
$\mathrm{NBM}$ & 1,23 & $\mathrm{R}$ & 1,12 & $\mathrm{r}$ \\
NB & 1,30 & $\mathrm{R}$ & 1,21 & $\mathrm{r}$ \\
$\mathrm{B}$ & 1,26 & $\mathrm{R}$ & 1,16 & $\mathrm{r}$ \\
\hline
\end{tabular}

Keterangan : *Kriteria penilaian C-organik tanah berdasarkan Balai Penelitian Tanah (2009). sr = sangat rendah; $\mathrm{r}=$ rendah; $\mathrm{s}=$ sedang; $\mathrm{t}=$ tinggi; $\mathrm{st}$ $=$ sangat tinggi. $\mathrm{P}=$ Perlakuan Petani (tanpa biochar + Urea, SP-36 dan $\mathrm{KCl}$ ), BM = Urea ditambah biochar dengan mikroba + SP-36 dan $\mathrm{KCl}$. $\mathrm{NB}=$ Urea ditambah nano biochar dengan mikroba + SP-36 dan $\mathrm{KCl} . \mathrm{NB}=$ Urea ditambah nano biochar + SP-36 dan $\mathrm{KCl} . \mathrm{B}=$ Urea ditambah biochar + SP-36 dan $\mathrm{KCl}$.

Menurut Bardgett (2005), terdapat dua cara dimana karbon organik tanah disimpan di dalam tanah, yaitu biomassa dari mikroba tanah dan residu tanaman yang terurai dengan mudah. Karbon yang disimpan pada biomassa permukaan tanah atau residu tanaman dilepaskan kembali ke atmosfer pada saat pembakaran atau dekomposisi dan terusmenerus. Ada suatu siklus dinamis dalam penyerapan, pengendapan, dan transformasi karbon antara udara dan tanah melalui tanaman (Dahal dan Bajracharya, 2010).

\section{Residu profenofos}

Berdasarkan hasil sidik ragam menunjukkan bahwa pemberian perlakuan urea ditambah biochar, urea ditambah biochar dengan mikroba, urea ditambah nano biochar, urea ditambah nano biochar dengan mikroba dan pupuk NPK tidak memberikan pengaruh yang nyata terhadap nilai residu profenofos tanah 35 HST dan 63 HST. Hasil analisis residu profenofos sebagaimana disajikan pada Tabel 4. 


\section{Jurnal Tanah dan Sumberdaya Lahan Vol 8 No 1: 27-34, 2021 \\ e-ISSN:2549-9793, doi: 10.21776/ub.jts1.2021.008.1.4}

Tabel 4. Hasil analisis residu profenofos.

\begin{tabular}{lccc}
\hline Perlakuan & \multicolumn{3}{c}{ Profenofos (ppm) } \\
\cline { 2 - 4 } & 35 HST & $\mathbf{6 3}$ & BMR \\
& & HST & (ppm) \\
\hline P & 0,001 & 0,129 & 0,1 \\
BM & 0,001 & 0,146 & 0,1 \\
NBM & 0,053 & 0,169 & 0,1 \\
NB & 0,063 & 0,169 & 0,1 \\
B & 0,091 & 0,205 & 0,1 \\
\hline
\end{tabular}

Keterangan : BMR (Batas Maksismum Residu) yang sudah ditetapkan oleh Badan Standarisasi Nasional (SNI 7313, 2008). P = Perlakuan Petani (tanpa biochar + Urea, SP-36 dan $\mathrm{KCl}$, $\mathrm{BM}=$ Urea ditambah biochar dengan mikroba + SP-36 dan $\mathrm{KCl}$. $\mathrm{NB}=$ Urea ditambah nano biochar dengan mikroba + SP-36 dan $\mathrm{KCl} . \mathrm{NB}=$ Urea ditambah nano biochar + SP-36 dan $\mathrm{KCl} . \mathrm{B}=$ Urea ditambah biochar + SP-36 dan $\mathrm{KCl}$.

Faktor-faktor yang menjadi pertimbangan apabila pestisida terserap oleh tanah adalah tercucinya pestisida dalam tanah (leaching), hal tersebut berpotensi sebagai pencemar perairan, berpengaruh terhadap mikroorganisme dalam tanah dan memungkingkan pestisida terdegradasi menjadi senyawa atau zat yang sangat beracun untuk manusia. Beberapa faktor yang mempengaruhi absorbsi pestisida adalah kelarutan, volatilisasi (kehilangan), polaritas (pemisahan) struktur dan ukuran molekulnya. Kekuatan terserapnya pestisida pada partikel tanah tergantung pada beberapa faktor antara lain interaksi antar dipol-dipol molekul pestisida dengan partikel muatan tanah, pertukaran kation tanah dan melalui ikatan hidrogen.

Populasi mikroba tanab

Pengamatan sifat tanah pada 35 dan 63 HST tidak memberikan pengaruh nyata terhadap populasi mikroba total tanah. Hasil analisis disajikan pada Tabel 5. Populasi mikroba pada sampel tanah pada berbagai perlakuan menunjukkan bahwa pada perlakuan menggunakan biochar lebih tinggi dibandingkan dengan yang tidak menggunakan biochar. Pada umur tanaman 35 dan 63 HST, populasi mikroba saat panen tertinggi pada perlakuan (B) yaitu sebesar $485 \times 10^{6}$ kemudian diikuti (NBM) sebesar $330 \times 10^{6}$. Peningkatan populasi mikroba berhubungan erat dengan status $\mathrm{pH}$ tanah. $\mathrm{pH}$ tanah pada perlakuan $\mathrm{B}$ memiliki kriteria netral $(6,6-7,5)$ menyebabkan peningkatan populasi mikroba 63 HST. Peningkatan populasi mikroba diikuti dengan peningkatan $\mathrm{pH}$ tanah 63 HST. Pada setiap mikroorganisme mempunyai respons yang berbeda-beda terhadap kondisi lingkungan baik dari suhu, $\mathrm{pH}$, kelembaban dan sebagainya.

Tabel 5. Hasil analisis mikroba total tanah.

\begin{tabular}{lcc}
\hline Perlakuan & \multicolumn{2}{c}{ Jumlah Mikroba $\left(\mathbf{c f u ~ m}^{-1}\right.$ ) } \\
\cline { 2 - 3 } & 35 HST & 63 HST \\
\hline P & $6,25 \times 10^{6}$ & $3,55 \times 10^{6}$ \\
BM & $3,55 \times 10^{6}$ & $3,80 \times 10^{6}$ \\
NBM & $780 \times 10^{6}$ & $330 \times 10^{6}$ \\
NB & $0,84 \times 10^{6}$ & $3,05 \times 10^{6}$ \\
B & $425 \times 10^{6}$ & $485 \times 10^{6}$ \\
\hline
\end{tabular}

Keterangan: $\mathrm{P}=$ Perlakuan Petani (tanpa biochar + Urea, SP-36 dan $\mathrm{KCl}$ ), BM = Urea ditambah biochar dengan mikroba + SP-36 dan $\mathrm{KCl}$. $\mathrm{NB}=$ Urea ditambah nano biochar dengan mikroba + SP-36 dan $\mathrm{KCl} . \mathrm{NB}=$ Urea ditambah nano biochar + SP-36 dan $\mathrm{KCl} . \mathrm{B}=$ Urea ditambah biochar + SP-36 dan $\mathrm{KCl}$.

Apabila kondisi lingkungan baik untuk perkembangan mikroba, dapat dipastikan proses degradasi oleh mikroba akan meningkat. Biochar merupakan tempat tinggal yang tepat dan sebagai sumber karbon dalam tanah untuk makanannya. Sesuai dengan penelitian Wahyuni et al., (2012) penggunaan biochar dapat meningkatkan populasi mikroorganisme tanah seperti berikut Azospirrillum sp; Bacillus sp; Chromobacterium, sp; Pseudomonas, sp., hal ini menunjukkan bahwa biochar dapat menjadi media tumbuh mikroba dengan baik dan degradasi oleh mikroba akan meningkat.

\section{Pengaruh perlakuan terhadap laju pertumbuhan bawang merah}

Berdasarkan hasil penelitian pengaruh pemberian perlakuan kombinasi urea ditambah biochar, nano biochar dan mikroba konsorsia terhadap laju pertumbuhan tanaman bawang merah diperoleh hasil data laju pertumbuhan panjang tanaman dan laju pertumbuhan jumlah daun tanaman bawang merah tidak begitu bervariasi.

\section{Laju pertumbuhan panjang tanaman}

Berdasarkan hasil pengukuran panjang tanaman bawang merah selama 56 HST menunjukkan bahwa rata-rata pertumbuhan panjang tanaman 


\section{Jurnal Tanah dan Sumberdaya Lahan Vol 8 No 1: 27-34, 2021 \\ e-ISSN:2549-9793, doi: 10.21776/ub.jts1.2021.008.1.4}

bawang merah per minggu yang tertinggi diperoleh pada perlakuan BM yaitu Urea ditambah biochar dengan mikroba + SP-36 dan $\mathrm{KCl}$, sedangkan yang terendah diperoleh pada perlakuan NBM yaitu Urea ditambah nano biochar dengan mikroba + SP-36 dan $\mathrm{KCl}$ (Gambar 1). Hal ini diduga karena penambahan biochar pada pupuk urea, biochar dapat menahan pelepasan $\mathrm{N}$ pada pupuk sehingga menjadi slow release. Biochar dapat dijadikan sebagai pupuk pelepas lambat (slow release fertilizer).

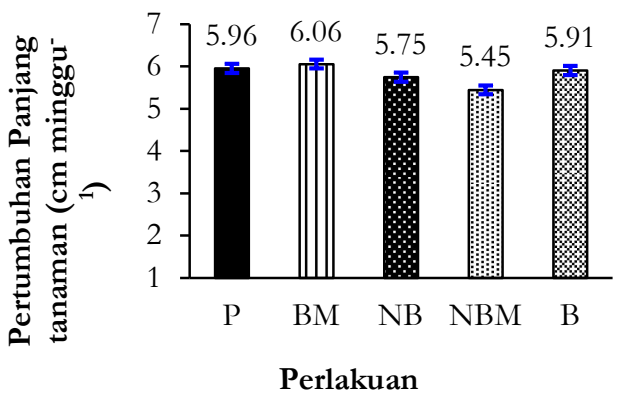

Gambar 1. Pengaruh pemberian kombinasi urea ditambah biochar pada laju pertumbuhan tinggi tanaman bawang merah. $\mathrm{P}=$ Perlakuan Petani (tanpa biochar + Urea, SP-36 dan $\mathrm{KCl}$ ), $\mathrm{BM}=$ Urea ditambah biochar dengan mikroba + SP-36 dan $\mathrm{KCl}, \mathrm{NBM}=$ Urea ditambah nano biochar dengan mikroba + SP-36 dan $\mathrm{KCl}, \mathrm{NB}$ $=$ Urea ditambah nano biochar + SP-36 dan $\mathrm{KCl}$, $\mathrm{B}=$ Urea ditambah biochar + SP-36 dan $\mathrm{KCl}$

Pupuk pelepas lambat merupakan pupuk dengan proses pelepasan unsur hara secara lambat mengikuti pola penyerapan unsur hara oleh tanaman (Ramadhani dan Widyaiswara, 2014). Bahan organik dalam biochar dapat memperbaiki struktur tanah sehingga dapat meningkatkan daya serap air tanah. Penambahan biochar dapat mengatasi kehilangan pupuk melalui beberapa cara diantaranya disebabkan oleh aliran permukaan/run off $(\mathrm{N}$, $\mathrm{P}, \mathrm{K})$, pencucian/leaching ( $\mathrm{N} \& \mathrm{~K})$, dan volatilization $(\mathrm{N})$. Selain itu, ada kecenderungan dengan penambahan mikroba ke dalam urea biochar meningkatkan pertumbuhan vegetatif tanaman yaitu panjang tanaman. Kandungan mikroba dalam urea biochar juga berperan dalam memperbaiki struktur dan tekstur tanah yang dapat meningkatkan daya serapan hara oleh akar dalam tanah. Selaras dengan pernyataan Gani
(2009) bahwa tingginya ketersediaan hara bagi tanaman juga merupakan hasil dari bertambahnya nutrisi secara langsung dari biochar, sehingga menyebabkan meningkatnya retensi hara dan perubahan dinamika mikroba tanah.

\section{Laju pertumbuhan jumlah daun}

Secara keseluruhan, rata-rata pertumbuhan jumlah daun bawang merah per minggu selama 56 HST pada semua perlakuan berkisar antara 2 - 3 helai daun. Perlakuan biochar (B) dan nano biochar (NB) tanpa maupun ditambah dengan mikroba (BM dan NBM) memberikan pengaruh yang lebih baik di dalam meningkatkan pertumbuhan jumlah daun dibandingkan dengan perlakuan petani (P) (Gambar 2).

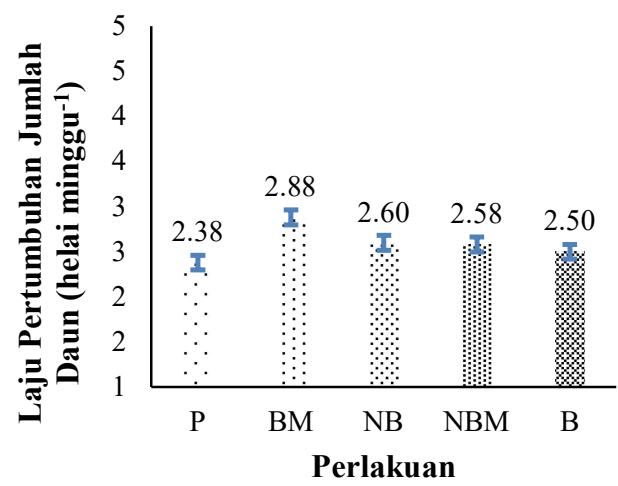

Gambar 2. Pengaruh pemberian kombinasi urea ditambah biochar pada pertumbuhan jumlah daun bawang merah. P = Perlakuan Petani (tanpa biochar + Urea, SP-36 dan KCl), $\mathrm{BM}=$ Urea ditambah biochar dengan mikroba + SP-36 dan $\mathrm{KCl}, \mathrm{NBM}=$ Urea ditambah nano biochar dengan mikroba + SP-36 dan $\mathrm{KCl}, \mathrm{NB}$ $=\mathrm{Urea}$ ditambah nano biochar $+\mathrm{SP}-36$ dan $\mathrm{KCl}$, $\mathrm{B}=$ Urea ditambah biochar + SP-36 dan $\mathrm{KCl}$

Pemberian perlakuan urea ditambah biochar dan mikroba memiliki hasil yang lebih tinggi dibandingkan dengan perlakuan lainnya, dengan nilai 2,88 helai minggu ${ }^{-1}$. Hasil laju pertumbuhan terendahpada perlakuan petani, dengan nilai 2,38 helai minggu ${ }^{-1}$. Hal ini diduga karena pengaruh penambahan biochar pada pupuk urea yang menyebabkan pelepasan $\mathrm{N}$ menjadi slow release sehingga asupan kebutuhan $\mathrm{N}$ pada tanaman dapat tercukupi sampai panen. Pemberian nitrogen yang tercukupi dapat 


\section{Jurnal Tanah dan Sumberdaya Lahan Vol 8 No 1: 27-34, 2021 \\ e-ISSN:2549-9793, doi: 10.21776/ub.jts1.2021.008.1.4}

membantu hormon sitokinin lebih responsif pada tanaman, sehingga pada perlakuan urea ditambah biochar cenderung lebih efektif. Hormon sitokinin berperan penting terhadap pertumbuhan tunas baru, jumlah tunas hingga jumlah daun. Hal ini selaras dengan pernyataan Lakitan (2008) bahwa nitrogen dalam jaringan tanaman merupakan komponen penyusun dari banyak senyawa esensial bagi tumbuhan, misalnya asam-asam amino. Nitrogen merupakan unsur penyusun protein dan enzim, selain itu juga terkandung dalam klorofil, hormon sitokinin dan auksin. Di samping itu, tidak bedanya pertumbuhan jumlah daun pada tanaman bawang merah sebagai akibat dari kemampuan biochar yang hanya membantu dalam menahan hara saja namun tidak menjadi sumber hara bagi tanaman (Sukartono et al., 2011).

\section{Kesimpulan}

Pemberian biochar dan nano biochar dengan mikroba konsorsia tidak memberikan pengaruh nyata. Pada 35 dan 63 HST pH tertinggi pada perlakuan B 5,84, dan 6,53. C-organik 35 dan 63 HST pada kriteria rendah yaitu $1,12-1,30 \%$. Populasi mikroba 35 dan 63 HST tertinggi pada prlakuan B yaitu sebesar $485 \times 10^{6}$. Laju pertumbuhan panjang tanaman tertinggi pada perlakuan BM dengan nilai $6,06 \mathrm{~cm}^{\text {minggu- }}{ }^{-1}$, sedangkan laju pertumbuhan jumlah daun pada perlakuan BM lebih tinggi dibandingkan dengan perlakuan lainnya, dengan nilai 2,88 helai minggu $^{-1}$.

\section{Ucapan Terima Kasih}

Penulis mengucapkan terima kasiuh kepada pimpinan dan staf Balai Penelitian Lingkungan Pertanian, Pati, Jawa Tengah, atas perkenan fasilitas rumah kasa dan laboratorium untuk pelaksanaan peneliti.

\section{Daftar Pustaka}

Afriyanto. 2008. Kajian Keracunan Pestisida Pada Petani Penyemprot Cabe di Desa Candi Kecamatan Bandungan Kabupaten Semarang. Tesis. Program Pasca Sarjana. Universitas Diponegoro. Semarang.

Balai Penelitian tanah. 2009. Petunjuk Teknis Analisis Kimia Tanah, Tanaman, Air, dan Pupuk.
Balai Penelitian Tanah. Bogor.

Bardgett, R.D. 2005. The Biology of Soil: A Community and Ecosystem Approach. Oxford University Press. New York.

Chan, K.Y., Van Zwieten, L., Meszaros, I., Downie, A. and Joseph, S. 2007. agronomic values of green waste biochar as a soil amendment. Australian Journal of Soil Research 45: 629-634.

Dahal, N. and Bajracharya, R.M. 2010. Prospects of soil organic carbon sequestration: implications for Nepal's mountain agriculture. Journal of Forest and Livelihood 9 (1): 125-136.

Agustin, S.E. dan Suntari, R. 2018. Pengaruh aplikasi urea dan kompos terhadap sifat kimia tanah serta pertumbuhan jagung (Zea mays L.) pada tanah terdampak erupsi Gunung Kelud. Jurnal Tanah dan Sumberdaya Lahan 5(1) : 775-783.

Gani, A. 2009. Potensi arang hayati biochar sebagai komponen teknologi perbaikan produktivitas lahan pertanian. IPTEK Tanaman Pangan 4(1) : $34-48$.

Lakitan, B. 2008. Dasar-dasar Fisiologi Tumbuhan. Raja Grafindo Persada. Jakarta.

Lehmann, J. and Joseph, S. 2009. Biochar for Environmental Management : Science and Technology. Earthscan, UK. pp 71-78.

Rahayu dan Berlian. 2010. Budidaya Bawang Merah. Penebar Swadaya. Jakarta.

Ramadhani dan Widyaiswara. 2014. Memperpanjang Umur Simpan Benih Jagung. Balai Besar Penelitian Pertanian Binuang. 261-272 hal.

Sohi, S., Capel, E.L., Kruul, E. and Bol, R. 2009. Biochar, Climate Change and Soil: A Review to Guide Future Research. CSIRO Land and Water Science Report.

Sukartono, Utomo, W.H., Nugroho, W.H. and Kusuma, Z. 2011. Simple biochar production generated from cattel dung and coconut shell. Jurnal of Basic and Applied Scientific Research $1(10): 1680-1685$.

Tang, J., Zhu, W., Kookana, R. and Katayama, A. 2013. Characteristics of biochar and its application in remediation of contaminated soil. Journal of Bioscience and Bioengineering 116(6): 653-659.

Wahyuni, Indratin, dan Ardiwinata, A.N. 2012. Teknologi Arang Aktif untuk Penanggulangan Pencemaran Residu Pestisida Klorfirifos di Lahan Sayuran Kubis. Prosiding Seminar Nasional Teknologi Pemupukan dan Pemulihan Lahan Terdegradasi. BBSDLP. Bogor. 449-456.

Wibowo, S. 2007. Budidaya Bawang Merah. Penebar Swadaya. Jakarta. 212 hal. 